\title{
POVEZANOST POTPORE I KONTROLE RODITELJA I NASTAVNIKA, ŠKOLSKOG USPJEHA I ZADOVOLJSTVA UČENIKA
}

\author{
Ivona Mršić \\ Janka Draškovića 19, 10000 Zagreb \\ ivonamrsic14@gmail.com \\ Andreja Brajša-Žganec \\ Institut društvenih znanosti Ivo Pilar \\ Marulićev trg 19/1, 1000101 Zagreb \\ andreja.brajsa.zganec@pilar.hr
}

\begin{abstract}
Sažetak
Cilj ovog istraživanja bio je ispitati povezanost učeničkih procjena potpore i kontrole nastavnika i roditelja, školskog uspjeha, zadovoljstva sobom kao učenikom i ispitne anksioznosti te razlike u navedenim varijablama s obzirom na spol. Ispitivanje je provedeno na 204 učenika prvih razreda triju gimnazijskih škola (141 učenice i 61 učenik). Korišteni mjerni instrumenti su: Ljestvica potpore i kontrole nastavnika konstruirana za potrebe ovog istraživanja, zatim Ljestvica potpore $i$ kontrole roditelja (Regner, Loose i Dumas, 2009), Podljestvica ispitne anksioznosti (Vulić-Prtorić i Sorić, 2002), mjere školskog uspjeha i zadovoljstva sobom kao učenikom. Utvrđeno je kako učenice, $u$ odnosu na učenike, imaju veću razinu ispitne anksioznosti, zadovoljnije su sobom kao učenikom, procjenjuju da dobivaju veću potporu od roditelja, te da ih nastavnici više kontroliraju. Učenici koji procjenjuju nižu razinu ispitne anksioznosti i veću potporu nastavnika i roditelja postižu bolji školski uspjeh i zadovoljniji su sobom kao učenikom. Potpora nastavnika jedini je značajan prediktor opće prosječne ocjene i zadovoljstva, uz kontrolu spola i ispitne anksioznosti. Potpora i kontrola roditelja, kao i kontrola nastavnika nisu se pokazale značajnim prediktorima školskog uspjeha i zadovoljstva učenika. Istraživanje ističe važnost socijalno-emocionalnih odnosa roditelja i nastavnika s učenicima, s ciljem osiguravanja odgojno-obrazovnih ishoda.
\end{abstract}

Ključne riječi: potpora i kontrola nastavnika i roditelja, školski uspjeh, zadovoljstvo učenika

\section{UVOD}

Dosadašnja istraživanja utvrdila su odrednice koje pridonose školskom uspjehu, a općenito ih možemo podijeliti na dva dijela: individualne karakteristike pojedinca 
kao što su inteligencija, spol, osobine ličnosti, interesi ili motivacija te okolinski činitelji, odnosno obitelj i škola (Adams i Ryan, 2005; Babarović, Burušić i Šakić, 2009; Luyten i Snijders, 1996; Sirin, 2005; Spinath, Spinath, Harlaar i Plomin, 2006). Koliko koje odrednice pridonose školskom uspjehu uvelike ovisi o nasljednim i okolinskim činiteljima, a do sada dobivene razlike u istraživanjima mogu se objasniti i razlikama u metodologiji, predmetu mjerenja i interesu istraživača.

Roditelji i nastavnici pokazali su se važnim socijalizacijskim čimbenicima koji oblikuju učeničke stavove i ponašanja, a njihov pozitivan utjecaj uvelike ovisi o kvaliteti interakcije i angažiranosti roditelja i nastavnika u toku obrazovno-odgojnog procesa djeteta.

Dosadašnja istraživanja mogućih odrednica roditeljske uključenosti u djetetovo obrazovanje najčešće su usmjerena na stupanj naobrazbe roditelja te socioekonomski status (Babarović, Burušić i Šakić, 2010; Sirin, 2005; Sui-Chu i Willms, 1996; Šimić Šašić, Klarin i Proroković, 2011), dok manji doprinos ide specifičnim obiteljskim varijablama poput stvarnog ponašanja roditelja usmjerenog na dječji uspjeh u školi. Sui-Chu i Willms (1996) razlikuju dva aspekta roditeljskog aktivnog doprinosa djetetovu obrazovanju: roditeljski nadzor učenja te općenito razgovore s djetetom o školi i obrazovanju, odnosno njihova podrška. Također, Model odnosa obitelj-škola Ryana i Adamsa (2005) obuhvaća relevantna obiteljska obilježja i procese koji bi mogli biti povezani sa školskim uspjehom i prilagodbom djeteta. Sadrži šest razina, među kojima je, uz djetetove i obiteljske karakteristike, navedena i razina obiteljske interakcije koja uključuje školske interese, a mogu uključivati roditeljsku pomoć oko domaće zadaće, raspravljanje o temama vezanim uz školu, korištenje strategija motiviranja djeteta i drugo.

Mnoga istraživanja utvrdila su pozitivno djelovanje roditelja na obrazovni uspjeh djeteta (Chen i Gregory, 2010; Deplanty, Coulter-Kern i Duchane, 2007; Epstein i Sheldon, 2002; Jackson-Peeples, 2012; Regner, Loose i Dumas, 2009; Sheldon i Epstein, 2006). Ona pokazuju kako djeca čiji su roditelji aktivno uključeni u njihove školske aktivnosti, imaju bolje ocjene, veću intrinzičnu motivaciju i bolju izvedbu školskih zadataka. Gregory i Weinstein (2004) utvrdili su kako podrška roditelja i nastavnika, kao i kontrola roditelja značajno predviđaju uspjeh u srednjim školama.

Osim prijatelja i obitelji, vrlo važan u školskom okruženju je odnos nastavnika prema učenicima. Novija istraživanja u razumijevanju interakcije nastavnik-učenik uključuju socijalno-emocionalnu komponentu prilikom poučavanja, naglašavajući važnost pozitivnih odnosa između nastavnika i učenika (Šimić-Šašić, 2011). Schmidt i Jacobson (1990) opisuju ponašanje nastavnika kao kontinuum koji se proteže od nadzora do humanističke orijentacije. Orijentacija na nadzor predstavlja kontrolirajuće razredno okruženje u kojemu je glavni cilj održavanje reda, dok se humanistička orijentacija odnosi na otvorenu interakciju, blizak odnos nastavnika i učenika, učeničku samostalnost. Kod učenika osnovnih i srednjih škola istraživanja su utvrdila obrazovne, društvene i emocionalne ishode pozitivnih odnosa s 
nastavnicima (Black i Deci, 2000; Gregory i Weinstein, 2004; Kususanto, Ismail i Jamil, 2010; Reeve i Jang, 2006; Šimić-Šašić, 2011). Ona pokazuju kako je podrška nastavnika povezana s većim osjećajem autonomije kod učenika, intrinzičnom motivacijom, samopoštovanjem, prilagodbom u školi, boljim školskim ocjenama i većim zadovoljstvom u školi. Wubbels i Brekelmans (2005) u preglednom radu navode rezultate istraživanja koja pokazuju da su nastavnikova sposobnost vodstva, pomaganje, razumijevanje i prijateljstvo pozitivno povezani, a strogost, opominjanje, nezadovoljstvo i nesigurnost negativno povezani s kognitivnim i afektivnim ishodima učenja.

Ispitna anksioznost pokazala se kao najvažniji ometajući čimbenik u školskom okruženju i najčešće je mjerena varijabla u osnovnoj školi, a budući da se u daljnjem obrazovanju učenici susreću sa sve zahtjevnijim zadacima, kriterijima uspješnosti i načinima prilagodbe, njezin intenzitet se također ispituje u srednjoj školi i na fakultetu. Mnoga istraživanja pokazuju malu, ali negativnu značajnu povezanost ispitne anksioznosti i školskog uspjeha (Mohorić, 2008; Peleg-Popko i Klingman, 2002; Vulić-Prtorić, 1992; Živčić-Bećirević, 2003). Nadalje, kvaliteta interakcije nastavnik-učenik i procesi unutar obitelji koji djeluju na djetetov školski uspjeh, mogu biti posredovani djetetovim psihološkim procesima, kao što su motiviranost, samoefikasnost i anksioznost (Adams i Ryan, 2005; Šimić-Šašić i Sorić, 2011).

Istraživanja razlika u obrazovnim ishodima s obzirom na spol djeteta u osnovnim školama pokazuju kako djevojke tijekom obrazovanja postižu bolje ocjene, ali su manje zadovoljne svojim postignućem u odnosu na mladiće (Babarović, Burušić i Šakić, 2009; Brajša-Žganec, Raboteg-Šarić i Franc, 2000; Rijavec i Marković, 2008; Živčić-Bećirević i Rački, 2006). Nadalje, utvrđeno je kako su djevojke anksioznije od mladića, osobito kod onih znakova anksioznosti koji su vidljivi u ponašanju te kako su spremnije o njima izvještavati (Karatas, Alci i Aydin, 2013; Putwain i Daly, 2014; Vulić-Prtorić, 1992; Živčić-Bećirević, 2003; Živčić-Bećirević i Rački, 2006). Isto tako djevojke procjenjuju da dobivaju veću podršku od odraslih, dok dječaci procjenjuju veću kontrolu od roditelja i nastavnika te se takvi rezultati objašnjavaju različitim spolnim ulogama djece stečenim procesom socijalizacije (Brajša-Žganec i sur., 2000; Zrilić, 2007).

Zadovoljstvo sobom kao učenikom promatrano je kao afektivna mjera školskog postignuća učenika s obzirom na to da se u prethodnim istraživanjima pokazalo također važnim područjem uspješnosti (Mohorić, 2008; Slavnić i Zečević, 2015; Živčić-Bećirević i Rački, 2006). Afektivni i socijalni razvoj učenika često se opisuje u ciljevima obrazovanja, ali unatoč svojoj važnosti, manje je istražen nego akademski razvoj učenika (Pang, 1996; prema Raboteg-Šarić, Šakić i Brajša-Žganec, 2009). Adolescenti imaju često ambivalentan odnos s roditeljima, od potrebe za samostalnošću do potrebe za podrškom i sigurnošću, a budući da znatan dio vremena provode u školi, školovanje i školska iskustva važno su područje adolescentskog života, te su im i dalje potrebni nastavnici i roditelji za uspješnu prilagodbu u školi, bolje školsko postignuće i zadovoljstvo školom (Buljan-Flander, 2013; Tian i Gilman, 
2009). S obzirom na rezultate prethodnih istraživanja, u našem istraživanju cilj je provjeriti povezanost školskog uspjeha, zadovoljstva sobom kao učenikom, ispitne anksioznosti, potpore i kontrole nastavnika i roditelja te razlike $u$ izraženosti navedenih varijabli ovisno o spolu učenika gimnazijskih škola. Također će se ispitati doprinos potpore i kontrole roditelja i nastavnika školskom uspjehu i zadovoljstvu sobom kao učenikom, uz kontrolu spola $\mathrm{i}$ ispitne anksioznosti.

\section{METODA}

\section{Sudionici}

U istraživanju su sudjelovala 204 učenika triju gimnazija općeg i jezičnog smjera u Zagrebu i Zaprešiću. U odabranom prigodnom uzorku, 141 je učenica i 61 učenik (dva sudionika nisu navela spol) u dobi od 14 do 16 godina $(\mathrm{M}=15,10$; $\mathrm{SD}=0,40)$.

\section{Postupak}

Sudjelovanje $u$ istraživanju bilo je dobrovoljno i anonimno, uz prethodnu suglasnost ravnatelja i stručnih suradnika škole te roditelja/skrbnika učenika. Učenici su ispunjavali instrumente samostalno, unutar pojedinog razrednog odjela na ustupljenim nastavnim satima razredne zajednice. Vrijeme ispunjavanja upitnika nije bilo strogo ograničeno, a u prosjeku je trajalo 20-25 minuta.

\section{Instrumenti}

Ljestvica potpore $i$ kontrole roditelja preuzeta je iz upitnika Perceptions of Parental and Teacher Academic Involvement (Regner i sur., 2009). Upitnik mjeri stupanj potpore i kontrole roditelja učenicima. Sadrži 8 čestica u kojima sudionik procjenjuje stupanj svog slaganja sa svakom česticom na ljestvici od 5 stupnjeva (od 1 U potpunosti se ne slažem do 5 U potpunosti se slažem), pri čemu viši rezultat upućuje na veću roditeljsku potporu ili kontrolu. Faktorskom analizom na zajedničke faktore, uz Varimax rotaciju, utvrđena su dva faktora koji zajednički objašnjavaju 58\% ukupne varijance. Prvi faktor objašnjava $29,04 \%$ varijance nakon rotacije, a uključuje 4 čestice koje opisuju potporu roditelja (primjerice: „Moji roditelj(i) razgovaraju sa mnom o mojim školskim problemima"), dok drugi faktor objašnjava $28,96 \%$ varijance nakon rotacije, a obuhvaća 4 čestice koje opisuju kontrolu roditelja (primjerice: „Moji roditelj(i) nadgledaju trudim li se za školu“). Dobivene podljestvice imaju zadovoljavajuće koeficijente unutarnje konzistencije ( $\alpha=0,74$ za podljestvi- 
cu roditeljske potpore i $\alpha=0,71$ za podljestvicu roditeljske kontrole). Rezultati na podljestvicama potpore $\mathrm{i}$ kontrole roditelja izražene su kao prosječne vrijednosti $u$ rasponu od 1 do 5 .

Ljestvica potpore $i$ kontrole nastavnika konstruirana je za potrebe našeg istraživanja. Ljestvica sadrži ukupno 15 čestica, od kojih je 10 preuzeto iz izvornih skala Teacher's Controlling Behavior i Teacher's Supportive Behavior (Kususanto i sur., 2010), dok je 5 dodano. Skala mjeri stupanj potpore i kontrole nastavnika nad učenicima. Sudionik procjenjuje stupanj svog slaganja sa svakom česticom na ljestvici od 5 stupnjeva (od 1 U potpunosti se ne slažem do 5 U potpunosti se slažem), pri čemu viši rezultat upućuje na veću potporu ili kontrolu nastavnika. Faktorskom analizom na zajedničke faktore, uz Varimax rotaciju, utvrđena su dva faktora koji zajednički objašnjavaju 42,24\% ukupne varijance. Prvi faktor objašnjava 26,42\% varijance nakon rotacije i opisuje potporu nastavnika (primjerice: „Moji nastavnici promijene svoj način rada kada je potrebno pomoći nekom učeniku“), dok drugi faktor objašnjava $15,82 \%$ varijance nakon rotacije i opisuje kontrolu nastavnika (primjerice: „Moji nastavnici često upozoravaju na disciplinu u razredu“). Koeficijent unutarnje konzistencije podljestvice potpore nastavnika iznosi $\alpha=0,84$, dok je unutarnja konzistencija podljestvice kontrole nastavnika $\alpha=0,73$. Prosječne vrijednosti rezultata na podljestvicama potpore i kontrole nastavnika izražene su u jedinicama skale $u$ rasponu od 1 do 5.

Podljestvica ispitne anksioznosti preuzeta iz Ljestvice anksioznosti za djecu - AFS (Vulić-Prtorić i Sorić, 2002) ispituje osjećaj bespomoćnosti i nelagode koji se pojavljuju u ispitnoj situaciji u obliku straha od zakazivanja u rješavanju zadataka, koji je često praćen reakcijama vegetativnog živčanog sustava. Učenik na svaku tvrdnju odgovara na jedan od tri načina: prihvaćanjem ponuđene tvrdnje i zaokruživanjem slova „T“, što mu donosi 2 boda, ne prihvaćanjem ponuđene tvrdnje i zaokruživanjem slova „N“, što mu donosi 0 bodova, te ako se ne može opredijeliti za jedan od ponuđenih odgovora zaokruživanjem ,??", što mu donosi 1 bod. Rezultat na ljestvici iskazuje se kao zbroj odgovora na česticama pojedine podljestvice. Podljestvica se sastoji od 15 tvrdnji (primjerice: „, Kada nastavnik ispituje, uvijek mi se pojavi neki čudan osjećaj u trbuhu“, „Vjerujem da bih u školi bolje uspijevao kada se ne bih toliko bojao pismenih i usmenih ispitivanja"), a maksimalan broj bodova je $30 \mathrm{Na}$ našem uzorku potvrđena je jednofaktorska struktura podljestvice ispitne anksioznosti koja objašnjava $31,44 \%$ varijance. Unutarnja konzistencija podljestvice u našem istraživanju pokazala se zadovoljavajućom $(\alpha=0,84)$.

Za procjenu školskog uspjeha korišten je opći uspjeh, pri čemu su učenici morali navesti svoju ocjenu na polugodištu zaokruženu na jednu decimalu i čestica zadovoljstvo sobom kao učenikom sa 4 stupnja, od 1, Nezadovoljan sam, ali nemam volje više se potruditi, do 4, Zadovoljan sam, trebam samo tako nastaviti. 


\section{REZULTATI I RASPRAVA}

U Tablici 1 prikazane su deskriptivne vrijednosti ispitanih varijabli: opće prosječne ocjene, zadovoljstva sobom kao učenikom, te podljestvica ispitne anksioznosti, potpore i kontrole nastavnika i roditelja.

Kolmogorov-Smirnovljevim testom testirana je normalnost raspodjela distribucija svih varijabli te je iz Tablice 1 vidljivo da raspodjela rezultata na svim varijablama značajno odstupa od normalne $(p<0,01)$. Ipak, uvidom u distribuciju rezultata, zbog nepostojanja ekstremnih odstupanja u zakrivljenosti i simetričnosti, smatra se opravdanim provoditi parametrijsku statistiku (Kline, 2005).

$\mathrm{U}$ Tablici 2 prikazane su spolne razlike ispitanih varijabli dobivene t-testom za nezavisne uzorke.

Utvrđena je statistički značajna razlika u varijabli zadovoljstvo sobom kao učenikom $(t=-2,15 ; p<0,05)$ i ispitne anksioznosti s obzirom na spol $(t=-3,60 ; p<0,01)$, na način da učenice u odnosu na učenike imaju veću razinu ispitne anksioznosti, ali su također zadovoljnije sobom kao učenikom. Mnoga istraživanja govore o većoj razini ispitne anksioznosti kod učenica u osnovnoj i srednjoj školi (Karatas i sur., 2013; Putwain i Daly, 2014; Vulić-Prtorić, 1992, Živčić-Bećirević, 2003; Živčić-Bećirević i Rački, 2006). Nadalje, neka istraživanja pokazuju kako su dječaci, u odnosu na djevojčice, zadovoljniji sobom bez obzira na slabiji školski uspjeh (Brajša-Žganec i sur., 2000; Živčić-Bećirević i Rački, 2006). U prethodnim istraživanjima rezultati su dobiveni na uzorku učenika osnovnih škola, dok naš uzorak obuhvaća učenike prvih razreda gimnazijskih škola te se može pretpostaviti kako se spolne razlike u zadovoljstvu školskim postignućem mogu mijenjati tijekom školovanja. Roditeljska potpora i kontrola nastavnika statistički se značajno razlikuju s obzirom na spol $(t=-2,39 ; p<0,05, t=-2,45 ; p<0,05)$, na način da učenice, $\mathrm{u}$ odnosu na učenike, izvještavaju da dobivaju veću potporu od roditelja i da ih na-

Tablica 1. Deskriptivna statistika varijabli korištenih u obradi podataka $(N=204)$

\begin{tabular}{lllrrrrr}
\hline Varijable & $\begin{array}{c}\text { Teorijski } \\
\text { raspon }\end{array}$ & Raspon & $M$ & $S D$ & SKW & KTS & $K-S$ \\
\hline Opća prosječna ocjena & $1-5$ & $1-5$ & 3,96 & 0,58 & $-1,02$ & 2,77 & $0,10^{*}$ \\
Zadovoljstvo & $1-4$ & $1-4$ & 2,63 & 0,74 & $-0,15$ & $-0,25$ & $0,28^{*}$ \\
Ispitna anksioznost & $0-30$ & $0-30$ & 16,68 & 7,13 & 0,31 & $-0,6$ & $0,08^{*}$ \\
Roditeljska potpora & $1-5$ & $1-5$ & 3,82 & 0,83 & $-0,88$ & 1,01 & $0,13^{*}$ \\
Roditeljska kontrola & $1-5$ & $1-5$ & 3,74 & 0,67 & $-0,79$ & 1 & $0,14^{*}$ \\
Potpora nastavnika & $1-5$ & $1-5$ & 3,04 & 0,75 & $-0,38$ & 0,02 & $0,09^{*}$ \\
Kontrola nastavnika & $1-5$ & $2-5$ & 3,84 & 0,53 & $-0,29$ & $-0,03$ & $0,08^{*}$ \\
\hline
\end{tabular}

Legenda: aritmetička sredina (M), standardna devijacija (SD), asimetričnost distribucije (SKW), spljoštenost distribucije (KTS), Kolmogorov-Smirnovljev test normaliteta distribucije (K-S), $* \mathrm{p}<0,01$ 
Tablica 2. Rezultati testiranja spolnih razlika u općoj prosječnoj ocjeni, zadovoljstvu sobom kao učenikom, ispitnoj anksioznosti, potpori i kontroli nastavnika i roditelja učenicima

\begin{tabular}{|c|c|c|c|c|c|c|}
\hline \multirow[b]{2}{*}{ VARIJABLE } & \multicolumn{2}{|c|}{$\begin{array}{c}\text { Učenici } \\
(N=61)\end{array}$} & \multicolumn{2}{|c|}{$\begin{array}{l}\text { Učenice } \\
(N=141)\end{array}$} & \multirow[b]{2}{*}{$t_{(1 ; 200)}$} & \multirow[b]{2}{*}{$p$} \\
\hline & $M$ & $S D$ & $M$ & $S D$ & & \\
\hline Opća prosječna ocjena & 3,94 & 0,56 & 3,97 & 0,59 & $-0,36$ & 0,72 \\
\hline Zadovoljstvo sobom kao učenikom & 2,46 & 0,74 & 2,70 & 0,73 & $-2,15$ & $0,03 *$ \\
\hline Ispitna anksioznost & 13,97 & 7,39 & 17,80 & 6,75 & $-3,60$ & $0,00 * *$ \\
\hline Roditeljska potpora & 3,61 & 0,91 & 3,91 & 0,78 & $-2,39$ & $0,02 *$ \\
\hline Roditeljska kontrola & 3,75 & 0,62 & 3,72 & 0,69 & 0,24 & 0,81 \\
\hline Potpora nastavnika & 2,89 & 0,81 & 3,10 & 0,71 & $-1,79$ & 0,08 \\
\hline Kontrola nastavnika & 3,70 & 0,59 & 3,90 & 0,49 & $-2,45$ & $0,02 *$ \\
\hline
\end{tabular}

Napomena: $* * p<0,01 ; * p<0,05$

stavnici više kontroliraju. Nisu utvrđene značajne razlike u općoj prosječnoj ocjeni na polugodištu, potpori nastavnika i kontroli roditelja između učenika i učenica. Sudionici su izražavali ocjene decimalnim brojem, čime se dobila realnija slika prosječnih ocjena o uspjehu u školi. S obzirom na to da su dječaci podložniji disciplinskim mjerama za neposlušno ponašanje i nedovoljan trud u nastavi, može se očekivati da će ih nastavnici više kontrolirati nego djevojčice. Međutim, Vrbešić (2007) je u svom istraživanju pokazala kako djevojčice, u odnosu na dječake, daju veću važnost nedisciplini, neaktivnosti na nastavi i neizvršavanju školskih obaveza prilikom objašnjavanja neuspjeha, što se zapravo objašnjava razlikama u odgoju, gdje se djevojčicama za uspjeh odmalena naglašava marljivost. Učenice u našem istraživanju procjenjuju da ih nastavnici više kontroliraju iz razloga što možda više uočavaju kako nastavnici upozoravaju na slabe ocjene i disciplinu, budući da im je važna marljivost, izvršavanje školskih obaveza i poslušnost. Nadalje, ranija istraživanja nisu utvrdila značajne razlike u kontroli roditelja promatranoj posebno za oca i majku s obzirom na spol (Sorić i Vulić-Prtorić, 2006; Šimić-Šašić, Klarin i Proroković, 2011), dok Brajša-Žganec i sur. (2000) pokazuju kako djevojčice percipiraju više podrške od roditelja i prijatelja, dok se podrška nastavnika nije pokazala statistički značajnom s obzirom na spol, što potvrđuje dobivene rezultate. Autorice dobivene rezultate objašnjavaju time kako se djevojčice općenito ponašaju više u skladu s očekivanjima roditelja koje se očituju u dobrom vladanju i boljem školskom uspjehu. Takvim ponašanjem djevojčice zauzvrat dobivaju i veće odobravanje i podršku, što ih i dalje potiče da se nastave tako ponašati. S druge strane moguće je da su djevojčice sklonije izražavanju emocija pa na podljestvici potpore roditelja izvještavaju kako im je važnije pomaganje i razumijevanje roditelja. Promjenom postojećih tradicionalnih uloga vjerojatno bi se i smanjile spolne razlike u promatranim varijablama našega istraživanja. 
Tablica 3. Dobivene korelacije ispitanih varijabli

\begin{tabular}{|c|c|c|c|c|c|c|c|}
\hline Varijable & 2 & 3 & 4 & 5 & 6 & 7 & 8 \\
\hline 1. Opća prosječna ocjena &, $42 * *$ &,$- 21 * *$ &,- 02 &,- 07 & ,16* &,- 03 &,- 03 \\
\hline 2. Zadovoljstvo sobom kao učenikom & &,$- 30 * *$ & ,19* & 04 & ,25** &, 03 &, $15 *$ \\
\hline 3. Ispitna anksioznost & & & ,08 & ,09 &,- 11 &, 10 & $25 * *$ \\
\hline 4. Potpora roditelja & & & &, $51 * *$ & ,20** & ,06 &, $17 *$ \\
\hline 5. Kontrola roditelja & & & & & ,13 & ,16* &,- 02 \\
\hline 6. Potpora nastavnika & & & & & & ,16* & ,13 \\
\hline 7. Kontrola nastavnika & & & & & & &, $17 *$ \\
\hline 8. Spol & & & & & & & 1 \\
\hline
\end{tabular}

Napomena: $* * p<0,01 ; * p<0,05$

S obzirom na korelacije ispitanih varijabli (Tablica 3), dobivena je nisko negativna značajna povezanost ispitne anksioznosti s općom prosječnom ocjenom na polugodištu $(r=-0,21 ; p<0,01)$ kao i sa zadovoljstvom sobom kao učenikom ( $r$ $=-0,30 ; p<0,01$ ), što pokazuju mnoga istraživanja (Mohorić, 2008; Peleg-Popko i Klingman, 2002; Šimić-Šašić i Sorić, 2011; Vulić-Prtorić, 1992; Živčić-Bećirević, 2003; Živčić-Bećirević i Rački, 2006). Nadalje, potpora roditelja pokazala se nisko pozitivno povezana jedino sa zadovoljstvom $(r=0,19 ; p<0,05)$, a potpora nastavnika nisko pozitivno povezana s općom prosječnom ocjenom $(r=0,16 ; p<0,05) \mathrm{i}$ zadovoljstvom sobom kao učenikom $(r=0,25 ; p<0,01)$. Iako adolescenti teže autonomiji i traženju identiteta i provode manje vremena s roditeljima, njima je potrebna emocionalna toplina, razumijevanje i podrška u prilagodbi školskom okruženju, zadovoljstvu i boljem školskom postignuću (Brajša-Žganec i sur., 2000; BuljanFlander, 2013). Isto tako, veća potpora nastavnika dovodi do većeg zadovoljstva učenika i opće prosječne ocjene, čime se pokazuje važnost pomaganja, povjerenja, interesa i prijateljstva koje nastavnik pokazuje prema učenicima. Nastavnici koji vjeruju u učenikove sposobnosti, prihvaćaju i potiču učenike na učenje, dovode do obostranog zadovoljstva i boljeg školskog uspjeha kod učenika bez obzira na predmet, učeničke sposobnosti ili razinu poučavanja (Dautbegović i Zvizdić-Meco, 2012). Kontrola roditelja i nastavnika nisu se pokazale značajno povezanima s ispitanim varijablama. Rezultati prijašnjih istraživanja nisu konzistentni. Prethodna istraživanja s jedne strane pokazuju pozitivnu povezanost školskog uspjeha s roditeljskim očekivanjima, kontrolom, nadgledanjem i raspravljanjem o napretku djeteta, a s druge strane negativnu povezanost školskog uspjeha s visokim očekivanjima roditelja i provjeravanjem domaće zadaće (Chen i Gregory, 2010; Deplanty i sur., 2007; Osburn i Stegman, 2004). Isto tako neka istraživanja pokazuju kako manje uspješni učenici procjenjuju ponašanje nastavnika kontrolirajućim, te da je nadzor nastavnika negativno povezan s kognitivnim i afektivnim ishodima učenjima (Ku- 
susanto i sur., 2010; Wubbels i Brekelmans, 2005). S druge strane, Bošnjak (1997) je pokazao kako nadzor nastavnika nije značajno povezan sa školskim uspjehom, što objašnjava time kako se učenici tijekom školovanja prilagode i postaju iskusniji u međusobnoj komunikaciji s nastavnicima, što smanjuje osjećaj pritiska i negativnog djelovanja na obrazovne ishode. Ovakvi rezultati istraživanja upućuju na višedimenzionalnost konstrukata potpore i kontrole nastavnika i roditelja te da neke njihove komponente mogu dovesti do pozitivnih, a druge do negativnih školskih ishoda učenika. Dobivena je također nisko pozitivna značajna povezanost potpore nastavnika i roditelja $(r=0,20 ; p<0,05)$, kao i kontrole nastavnika i roditelja $(r=$ $0,16 ; p<0,05)$, što potvrđuje nalaze i teorijska objašnjenja o važnosti odnosa nastavnika i roditelja kao glavnih socijalizacijskih čimbenika u odgojno-obrazovnom sustavu djeteta (Adams i Ryan, 2005; Brajša-Žganec i Slaviček, 2014; Chen i Gregory, 2010; Gregory i Weinstein, 2004; Regner i sur., 2009). Treba naglasiti kako dobiveni rezultati u našem istraživanju imaju niske povezanosti i kako se rezultati temelje na korelacijskoj analizi, pa se ne može zaključiti o uzročno-posljedičnoj vezi između učeničkih procjena potpore i kontrole roditelja i nastavnika, ispitne anksioznosti i školskog uspjeha.

U Tablici 4 prikazane su dvije zasebne hijerarhijske regresijske analize s općom prosječnom ocjenom i zadovoljstvom sobom kao učenikom kao kriterijskim

Tablica 4. Rezultati hijerarhijskih regresijskih analiza spola, ispitne anksioznosti, kontrole i potpore nastavnika i roditelja pri predikciji opće prosječne ocjene i zadovoljstva sobom kao učenikom

\begin{tabular}{|c|c|c|c|c|}
\hline \multirow[b]{2}{*}{ Varijable } & \multicolumn{2}{|c|}{$\begin{array}{c}\text { Opća } \\
\text { prosječna ocjena }\end{array}$} & \multicolumn{2}{|c|}{$\begin{array}{l}\text { Zadovoljstvo sobom } \\
\text { kao učenikom }\end{array}$} \\
\hline & $\beta$ & $\Delta R^{2}$ & B & $\Delta R^{2}$ \\
\hline Korak 1 & & 052 & & , 147 \\
\hline Spol &, 03 & &, $24 * *$ & \\
\hline Ispitna anksioznost &,$- 21 * *$ & &,$- 36^{* *}$ & \\
\hline$F_{(2,199)}$ & $5,28^{* *}$ & & $17,17^{* *}$ & \\
\hline Korak 2 & & ,023 & &, 042 \\
\hline Potpora roditelja &,- 05 & &, 10 & \\
\hline Kontrola roditelja &,- 03 & &,- 01 & \\
\hline Potpora nastavnika &, $15^{*}$ & &, $18^{*}$ & \\
\hline Kontrola nastavnika &,- 03 & &,- 01 & \\
\hline$F_{(4,195)}$ & $2,05^{*}$ & & $2,51 *$ & \\
\hline \multicolumn{5}{|l|}{ Sve varijable } \\
\hline$R^{2}$ & & ,075 & & , 189 \\
\hline$F_{(6,195)}$ & $2,56^{*}$ & & $7,57 * *$ & \\
\hline
\end{tabular}

Napomena: $* * \mathrm{p}<.01 ; * \mathrm{p}<.05$ 
varijablama te učeničkim procjenama potpore i kontrole roditelja i nastavnika kao prediktorskim varijablama, uz kontrolu spola i ispitne anksioznosti.

Kada razmotrimo varijablu opće prosječne ocjene na polugodištu, kontrolirajući razlike po spolu i ispitnoj anksioznosti u rezultatima sudionika koje objašnjavaju $5,2 \%$ varijance kriterija $\left(F_{(2,199)}=5,28 ; p<0,01\right)$, rezultati na podljestvicama Potpore i Kontrole nastavnika te Potpore $i$ Kontrole roditelja dodatno objašnjavaju samo $2,3 \%$ ukupne varijance ovoga kriterija $\left(F_{(4,195)}=2,05 ; p<0,05\right)$, pri čemu je jedini značajni prediktor Potpora nastavnika $(\beta=0,15 ; p<0,05)$. Kontrolirajući razlike po spolu i ispitnoj anksioznosti u rezultatima sudionika koje objašnjavaju 14,7\% varijance kriterijske varijable zadovoljstva sobom kao učenikom $\left(F_{(2,199)}=17,17 ; p\right.$ $<0,01)$, rezultati na podljestvicama Potpore i Kontrole nastavnika te Potpore i Kontrole roditelja dodatno objašnjavaju samo 4,2\% ukupne varijance ovoga kriterija $\left(F_{(4,195)}=2,51 ; p<0,05\right)$, pri čemu je jedini značajni prediktor Potpora nastavnika $(\beta=0,18 ; p<0,05)$. Nakon kontrole spola i ispitne anksioznosti, Potpora i Kontrola roditelja i Kontrola nastavnika nisu se pokazali značajnim prediktorima opće prosječne ocjene i zadovoljstva sobom kao učenikom. Rezultati pokazuju kako učenici koji procjenjuju da dobivaju veću potporu od nastavnika, imaju i veću opću prosječnu ocjenu i izvještavaju o većem zadovoljstvu sobom kao učenikom. Kususanto i sur. (2010) su u svom istraživanju predviđali samopoštovanje na temelju potpore i kontrole nastavnika te su utvrdili kako je potpora nastavnika značajan prediktor samopoštovanja kao učenikove procjene vlastite vrijednosti. Isto tako, Gregory i Weinstein (2004) utvrdili su kako se, uz podršku i kontrolu roditelja i nastavnika, najboljim prediktorom pokazala podrška nastavnika. Uspostavljajući snažan i podržavajući odnos s nastavnicima, učenici se osjećaju sigurnije u školskom okruženju, zadovoljnije svojim školskim sposobnostima, bolje se društveno prilagođavaju, te ostvaruju bolje školske rezultate. Podrška nastavnika koja dovodi do većeg zadovoljstva učenika i boljih ocjena pokazuje kako je osim prenošenja znanja, važno i uspostavljanje socijalno-emocionalnih odnosa. Djeca teže za prihvaćanjem i potporom, stoga podrška kod kuće i u školi kao i međusobna suradnja roditelja i škole pomažu učenicima u njihovu razvoju i prilagodbi školskom okruženju.

Svakako treba spomenuti i ograničenja ovog istraživanja. Istraživanje je provedeno na malom i prigodnom uzorku gimnazijskih učenika i kao takvo ograničava mogućnost generalizacije dobivenih rezultata na učenike drugih dobnih skupina ili obrazovnih usmjerenja. Nadalje, istraživanje obuhvaća potporu i kontrolu nastavnika i roditelja u ispitivanju okolinskih odrednica školskog uspjeha, a postoji velik broj drugih okolinskih obilježja koji mogu utjecati na postignuće učenika, od procesa unutar obitelji do škole kao ustanove. Isto tako, pojedini neznačajni prediktori imaju nelinearan odnos sa školskim uspjehom i/ili su kolinearni s drugim prediktorskim varijablama, čime se mogu objasniti dobiveni rezultati regresijskih analiza ovog istraživanja. Svakako bi u budućim istraživanjima trebalo ispitati dodatna inidividualna i okolinska obilježja, a koja su se u prijašnjim istraživanjima pokazala izravno i/ili neizravno povezanima sa školskim uspjehom i zadovoljstvom 
sobom kao učenikom. Uvođenjem dodatnih varijabli dobio bi se bolji uvid u složenu interakciju obitelji, škole i školskog uspjeha djece u srednjim školama. Bilo bi korisno prikupiti procjene od strane roditelja i nastavnika te tako dobivene podatke usporediti s učeničkim procjenama o ponašanju nastavnika i roditelja. Uvođenjem također drugih mjera akademskog uspjeha poput standardiziranih testova postignuća, procjena od strane nastavnika ili socijalne prilagodbe djeteta u školi i korištenja određene ljestvice školskog zadovoljstva, dobio bi se bolji uvid u školsko funkcioniranje djeteta. Uz objektivne procjene školskog uspjeha (ocjene, testovi), valjan su izvor podataka i subjektivne procjene školskog uspjeha (zadovoljstvo, motiviranost, stavovi) koje bi svakako trebalo češće uključivati u ispitivanje odrednica uspješnosti učenika.

\section{LITERATURA}

Adams, G. R., Ryan, B. A. (2005). The family-school relationships model: Parental influences on school success, <http://www.uoguelph.ca/ gadams/Theses/Adams-FamilySchool-Relationship-Model.pdf>. Pribavljeno 20. 05. 2015.

Babarović, T., Burušić, J., Šakić, M. (2009). Uspješnost predviđanja obrazovnih postignuća učenika osnovnih škola Republike Hrvatske. Društvena istraživanja, 18, 673-695

Babarović, T., Burušić, J., Šakić, M. (2010). Psihosocijalne i obrazovne odrednice školskog uspjeha učenika osnovnih škola: dosezi dosadašnjih istraživanja - pregledni rad. Suvremena psihologija, 13, 235-256.

Black, A. E., Deci, E. L. (2000). The effects of instructors' autonomy support and students' autonomous motivation on learning organic chemistry: A self-determination theory perspective. Science Education, 84, 740- 756.

Bošnjak, B. (1997). Drugo lice škole: istraživanje razredno-nastavnog ozračja. Zagreb: Alinea.

Brajša-Žganec, A., Raboteg-Šarić, Z., Franc, R. (2000). Dimenzije samopoimanja djece u odnosu na opaženu socijalnu podršku iz različitih izvora. Društvena istraživanja, 9, 897-912.

Brajša-Žganec, A., Slaviček, M. (2014). Obitelj i škola: utjecaj obiteljskog sustava na funkcioniranje djeteta u školi. U A. Brajša-Žganec, J. Lopižić i Z. Penezić (ur.), Psihološki aspekti suvremene obitelji, braka i partnerstva (str. 149-173). Zagreb: Hrvatsko psihološko društvo i Naklada Slap.

Buljan-Flander, G. (2013). Adolescencija - izazovi odrastanja, <http://www.poliklinikadjeca.hr/aktualno/teme/adolescencija-\%E2\%80\%93-izazovi-odrastanja/>. Pribavljeno 20. 05. 2015.

Chen, W. B., Gregory, A. (2010). Parental involvement as a protective factor during the transition to high school. The Journal of Educational Research, 151, 53-62.

Dautbegović, A., Zvizdić-Meco, S. (2012). Determinante nezadovoljstva školom mladih adolescenata, <http://www.academia.edu/8177491/Determinante nezadovoljstva_\%C5\%A1kolom_mla\%C4\%91ih_adolescenata $>$. Pribavljeno 20. 05. 2015. 
DePlanty, J., Coulter-Kern, R., Duchane, K. A. (2007). Perceptions of parents involvement in academic achivement. Journal of Educational Research, 100, 361-368.

Epstein, J. L., Sheldon, S. B. (2002). Present and accounted for: Improving student attendance through family and community involvement. The Journal of Educational Research, 95, 308-318.

Epstein, J. L., Sheldon, S. B. (2006). Moving forward: Ideas for research on school, family i community partnerships. U Conrad, C. F. i Serlin, R. (ur.). SAGE Handbook for research in education: Engaging ideas and enriching inquiry (str. 117-138). Thousand Oaks, CA: Sage Publications.

Gregory, A., Weinstein, R. S. (2004). Connection i regulation at home and in school: Predicting growth in achievement for adolescents. Journal of Adolescent Research, 19, 405-427.

Jackson-Peeples, J. (2012). Relationships between perceived levels of parental involvement and student achievement on Stanford achievement tests. Ed. D. Dissertations. Illinois: Olivete Nazarene University.

Luyten, H., Snijders, T.A.B. (1996). School effects and teacher effects in Dutch elementary education. Educational Research and Evaluation, 2, 1-24.

Karatas, H., Alci, B., Aydin, H. (2013). Correlation among high school senior students' test anxiety, academic performance and point of university entrance exam. Educational Research and Reviews, 8, 919-926.

Kline, R. B. (2005). Principles and Practice of Structural Equation Modeling. New York: Guilford.

Kususanto, P., Ismail, H. Z., Jamil, H. (2010). Students' self-esteem and their perception of teacher behavior: A study of between-class ability grouping. Electronic Journal of Research in Educational Psychology, 8, 707-724.

Mohorić, T. (2008). Automatske misli kod učenja i ispitna anksioznost kao odrednice subjektivnoga i objektivnoga akademskog postignuća studenata. Psihologijske teme, 17, $1-14$.

Osburn, M. Z., Stegman, C. (2004). Parents' perceptions of standardized testing: Its relationship and effect on student achievement. Journal of Educational Research and Policy Studies, 4, 75-95.

Peleg-Popko, O., Klingman, A. (2002). Family enviroment, discrepancies between perceived actual and desirable environment, and children's test and trait anxiety. British Journal of Guidance and Counselling, 30, 451-466.

Putwain, D., Daly, A. L. (2014). Test anxiety prevalence and gender differences in a sample of English secondary school students. Educational Studies, 40, 554-570.

Raboteg-Šarić, Z., Šakić, M., Brajša-Žganec, A. (2009). Kvaliteta života u osnovnoj školi: povezanost sa školskim uspjehom, motivacijom i ponašanjem učenika. Društvena istraživanja, 18, 697-716.

Reeve, J., Jang, H. (2006). What teachers say and do to support students' autonomy during a learning activity. Journal of Educational Psychology, 98, 209-218.

Regner, I., Loose, F., Dumas, F. (2009). Students' perceptions of parental and teacher academic involvement: Consequences on achievement goals. Europan Journal of Psychology of Education, 24, 263-277. 
Rijavec, M., Marković, D. (2008). Nada, strah od ispitivanja i školski uspjeh. Metodika, 9, 8-17.

Schmidt, L.J., Jacobson, M.H. (1990). Pupil control in the school climate. $<$ http://files.eric. ed.gov/fulltext/ED319692.pdf>. Pribavljeno 24. 4. 2016.

Sirin, S.R. (2005). Socioeconomic status and academic achievement: A meta-analytic review of research 1990-2000. Review of Educational Research, 75, 417-453.

Slavnić, D. i Zečević, I. (2015). Učeničko zadovoljstvo životom, školom i samopoštovanje. U S. Subotić (ur.), STED 2015. zbornika radova iz psihologije (str. 75-86). Banja Luka, BIH: Fakultet za poslovni inženjering i menadžment.

Sorić, I., Vulić-Prtorić, A. (2006). Percepcija roditeljskog ponašanja, školska samoefikasnost i kauzalne atribucije u kontekstu samoregulacije učenja. Društvena istraživanja, 15, 773-797.

Spinath, B., Spinath, F.M., Harlaar, N., Plomin, R. (2006). Predicting school achievement from intelligence, self-perceived ability, and intrinsic value. Intelligence, 34, 363-374.

Sui-Chu, E. i Willms, J. D. (1996). Effects of parental involvement on eight-grade achievement. Sociology of Education, 69, 126-141.

Šimić-Šašić, S. (2011). Interakcija nastavnik-učenik: Teorije i mjerenje - pregledni rad. Psihologijske teme, 20, 233-260.

Šimić-Šašić, S., Klarin, M., Proroković, A. (2011). Socioekonomske prilike obitelji i kvaliteta obiteljske interakcije kao prediktori školskog uspjeha srednjoškolaca u Hrvatskoj, Bosni i Hercegovini i Makedoniji. Ljetopis socijalnog rada, 18, 31-62.

Šimić-Šašić, S., Sorić, I. (2011). Kvaliteta interakcije nastavnik-učenik: povezanost s komponentama samoreguliranog učenja, ispitnom anksioznošću i školskim uspjehom. Suvremena psihologija, 14, 35-55.

Tian, Li li; Gilman, Rich (2009). School satisfaction among Chinese mainland adolescents. Scientific Journal Publishers, 37, 1095-1100.

Vrbešić, S. (2007). Atribucije školskog uspjeha i neuspjeha s obzirom na rod i strah od ispitivanja. Diplomski rad. Zagreb: Filozofski fakultet.

Vulić-Prtorić, A. (1992). Ispitivanje povezanosti anksioznosti, uspjeha u školi i sociometrijskog statusa učenika osnovne škole. Primijenjena psihologija, 13, 53-63.

Vulić Prtorić, A., Sorić, I. (2002). Skala anksioznosti za djecu - AFS. U Lacković- Grgin i sur. (ur.), Zbirka psihologijskih skala i upitnika - Svezak 1 (str. 123-129). Zadar: Filozofski fakultet.

Wubbels, T., Brekelmans, M. (2005). Two decades of research on teacher-student relationships in class. International Journal of Educational Research, 43, 6-24.

Zrilić, S. (2007). Neke potencijalno relevantne sociodemografske varijable školskih izostanaka. Odgojne znanosti, 9, 41-65.

Živčić-Bećirević, I. (2003). Uloga automatskih misli i ispitne anksioznosti u uspjehu studenata. Društvena istraživanja, 12, 703-720.

Živčić-Bećirević, I., Rački, Ž. (2006). Uloga automatskih misli, navika učenja i ispitne anksioznosti u objašnjenju školskog uspjeha i zadovoljstva učenika. Društvena istraživanja, 15, 987-1004. 


\title{
THE RELATIONSHIP OF TEACHER AND PARENTAL SUPPORT AND MONITORING, SCHOOL ACHIEVEMENT AND STUDENT SATISFACTION
}

\begin{abstract}
The aim of this research was to investigate the relationship between students' perception of parental and teacher support and monitoring, school achievement, satisfaction with a role of being a student and test anxiety, as well as differences in those variables with regard to gender. The research was conducted on 204 students from the first grade of three gymnasiums (141 female students and 61 male students). Instruments used in the study were: Scale of teacher support and monitoring constructed for this research, Scale of parental support and monitoring (Regner, Loose and Dumas, 2009), Subscale of test anxiety (Vulić-Prtorić and Sorić, 2002), as well as measurements of school achievement and satisfaction with a role of being a student. The results showed that female students, compared to male students, have higher level of test anxiety, that they are more satisfied with their role of being a student, observe higher level of parental support, as well as teacher monitoring. Students who reported a lower level of test anxiety and higher teacher and parental support assessed level of their own school achievement and satisfaction as better. With control of gender and test anxiety, teacher support was found to be the only significant predictor of average grade and satisfaction. Parental support and monitoring as well as teacher control were not found to be significant predictors of school achievement and student satisfaction. The study highlights the importance of teacher-student and parent-student relationship, which ensures educational outcomes for students.
\end{abstract}

Key words: parental and teacher support and monitoring, school achievement, student satisfaction

Prihvaćeno za tisak: 30. 04. 2016. 